\title{
Universal Old Age Pension and Spatial Aspects of Its Impacts on Sustainable Livelihoods in Lesotho
}

\author{
Vusi Mashinini \\ Department of Geography and Environmental Science, National University of Lesotho, Lesotho
}

Received September 10, 2019; Revised October 21, 2019; Accepted October 27, 2019

Copyright $@ 2019$ by authors, all rights reserved. Authors agree that this article remains permanently open access under the terms of the Creative Commons Attribution License 4.0 International License

\begin{abstract}
The aim of this paper is to assess the spatial impacts of universal old age pension on sustainable livelihoods of the elderly in Lesotho. It uses sustainable livelihoods framework to analyse primary data collected from field work done in an urban and a rural community to assess the differential spatial impacts of the universal old age pension on sustainable livelihoods in Lesotho. The working hypothesis of the research was that the universal old age pension provides the elderly with access to some income to use for access to basic needs for livelihoods but that this impact varies in space between rural and urban communities. The results indicate that the impacts are viewed as positive by interviewees, but slightly differ in urban and community settings. The paper concludes that in general the universal old age pension promotes equal access to income for all people above 70 years. Although the impacts of this income differ between rural and urban communities, they ensured that the elderly people were not left behind in access to livelihoods and therefore promoted inclusive development. However, there were also some challenges that need policy attention for the pension to contribute more sustainable impacts in both rural and urban areas of Lesotho. The overall conclusion was that, spatially, the impacts of the universal old age pension were felt more in the rural than urban area of the study.
\end{abstract}

Keywords Sustainable Livelihoods, Universal Old Age Pension, Lesotho

\section{Introduction}

Lesotho is a small land locked state of 30355 square kilometres in size surrounded by South Africa in southern Africa. Lesotho has a population of 2.2 million and is one of the Least Developed Countries in the world. In 2017 it was classified a low human development country under the UNDP Human Development Index (HDI) with an HDI score of score of 0.520 and rank of number 159 out of the 189 countries. The Gross Domestic Product (GDP) per capita fluctuates but was USD 1,154 in 2017. The economy is poor with a GDP of USD 2,578 million in 2017. The share of agriculture to the economy has been declining over the years and was 6\% to GDP in 2016. Estimates are that more than 600, 000 households are at the risk of hunger and need food aid support at any point in time throughout the year. Unemployment is high estimated officially at $25 \%$ of the labour force of some 800,000 people in the economically active age group. In particular youth unemployment is rife at $15.3 \%$ (African Economic Outlook, 2012: 2). The once acute unemployment of women is reduced by their preferential employment in the garment industries started since 2000 under the auspices of the AGOA. Income inequality and associated poverty are high and it is estimated at $57 \%$ of all households live below basic needs poverty line of USD 1.9 dollars per day; while $34 \%$ live below food poverty line of USD 0.61 dollar per day. There is also inequality in regional terms so that $58 \%$ of rural households live basic needs below poverty line while $40 \%$ of urban households do so. The Gini coefficient is 0.54 . This suggests high inequality of access to income. Moreover, in 2003 the top $10 \%$ of households lived on $40 \%$ of all income and the bottom $10 \%$ only shared the remaining $1 \%$ of national income; while in 2003 the top $20 \%$ had access to $56 \%$ of national income compared to the bottom $20 \%$ who shared only $3 \%$ of the national income (index mundi, undated). This inequality of income also has implications for inequality of access to basic services such as education, health, energy.

In the case of population and health, the population of Lesotho is 1.9 million, of which $77 \%$ are rural and $23 \%$ reside in urban areas. $24 \%$ of the population is HIV positive, making the country to be the $2^{\text {nd }}$ worst affected by the pandemic in the world. $40 \%$ of the population is $15-35$ years. Life expectancy is 54 years; Infant mortality rate is 94 per 1000 live births; child mortality rate is at 24 per 1000; and maternal mortality rate is at 939 per 100, 000 
live births (Ministry of Education, 2015:7). Concerning education, the literacy rate is $81 \%$ for men and $97 \%$ for women between 15-49 years. Since literacy goes hand in hand with skills and training for employment in the labour market, the illiteracy rate implies inequality of opportunities to employment (Kingdom of Lesotho, 2013: XII). In the case of energy, $16 \%$ has access to electricity, while 49\% use biomass. (Ministry of Education, 2015: 5).

Inequality also has spatial dimensions in the country. In general, the mountain regions are worse of in terms of both income and access to basic services compared to their lowlands region. Similarly, the rural areas are worse off in income and access to basic services than the urban areas; and there are specific intra-regional inequalities between mountains, foothills and lowlands as well. The provisioning of income, infrastructure and services is highly skewed in favour of the lowlands which have all weather roads whereas mountain regions are mostly inaccessible by vehicle due to lack of all-weather roads.

Lesotho has implemented the use of universal old age pension since 2004 (Kingdom of Lesotho, 2014) to minimise intergenerational poverty in which the total absence of or very poor access to income by the elderly citizens deprive them of access to sustainable livelihoods.

The Government expects that its use of the universal old pension which started under the Millennium Development Goals (MDGs) (Kingdom of Lesotho, 2013) and continues under the Sustainable Development Goals (SDGs) will enable Lesotho to promote inclusive development through a guarantee that the beneficiary old age pensioners are not left behind in access to livelihoods. This study provides data on the impacts from the viewpoint of the old age pensioners from two villages in order to contribute towards further understanding on this matter. Section one of the paper is the introduction; section two is literature review on sustainable livelihoods and universal old age pension; section three is on methodology; section four presents field data results and discussion. Section five provides the conclusion and recommendations.

\section{Universal Old Age Pension and Sustainable Livelihoods: Overview of Literature}

The analytical framework of this study is based on sustainable livelihoods analysis (SLA) developed by the Department for International Development (DFID) (1999) and is widely used by analysts to assess the impacts of policies, programmes and projects on the livelihoods of the beneficiaries. According to the SLA sustainable livelihoods of the beneficiaries are based on access to livelihood assets under the five components of capital which are financial, human, social, natural and physical capitals; so that they can reduce vulnerability, devise and embark on livelihood strategies that result in livelihood outcomes. The merit of interventions is in how far they maximise positive outcomes and minimise vulnerability of the beneficiaries. One of the many challenges in the use of the SLA is how participatory it is in order to reflect the benefits or positive impacts on livelihoods as seen and felt by the beneficiaries themselves rather than the implementers, planners and evaluators of the interventions (Valdes-Rodriguez and Perez-Vazquez, 2011). This issue is relevant for the present study because it makes a deliberate attempt to view the contribution of impacts of old age pension as perceived by the recipients themselves. Moreover it also takes into account that impacts may differ between rural and urban recipients and therefore compares these differential settings.

The general definition of old age pension is that it is a regular, often monthly, monetary pay that people receive from the government because they no longer work due to old age. Literature differentiates between two types of pensions, namely contributory and noncontributory pension. Contributory pension is the pension for which the recipients have paid full or partial contributions during their working life time in order to qualify. In cases where they paid partly, their employers would have paid the other part on their behalf while at work. Therefore employees get the pension on retirement. Contributory pension can be voluntary or it can be forced. Voluntary contributory pension is one in which a person willingly agrees with their employer to deduct a certain amount of money from their income every month to pay it into the pension fund; or the person actually pays it themselves into that pension fund. On the other hand compulsory contributory pension is one in which the state forces people to contribute through the use of legislation that binds employers to deduct a certain percentage from each of its employees' incomes for contribution into the pension fund against their names or it levies special tax whose proceeds go into the pension fund. The advantages of contributory pension are that it prepares the recipients for the time when they are no longer at work in order to be able to afford access to basic goods and services and thus avoid falling back to poverty. The disadvantages are that it is selective in favour of only those who worked; and who, in most cases, tend to be men in developing countries. Thus most women are excluded by contributory pension if they never had formal employment. Moreover people who are disabled and could not find formal employment as a result of living with their disabilities are also excluded from contributory pension mostly (Willmore, 2006).

Non-contributory pension on the other hand is that pension for which no earlier contributions during one's formal working life span are necessary to qualify. Instead the state takes it as its responsibility to ensure that its citizens who are elderly or beyond working age are assisted with some income to cope with basic livelihood requirements. The state itself gets the money from its old age pension fund that receives finance from the national 
budget, and is regulated by the appointed Ministry, often the Ministry of Social Welfare. Therefore it is inclusive because it is accessible to all nationals by virtue of having attained the specified old age and citizenship. It also has no gender bias against women. Hence it is also called universal old age pension (Willmore, 2006). While in some countries age is the main criterion that makes people to qualify; in others it is both age and lack of constant regular income from accumulated resources during earlier years. In yet others if one earns a work related retirement pension one may not qualify to earn universal pension as well. While in the past universal old age pensions were used mainly in developed countries, today it is a common strategy used in developing countries in Asia, Latin America and Africa as well. Studies done in South Korea (Shin \& Kyung Do, 2015), China (Liu \& Sun, 2016), India (Lal, 2015; Ranya, 2014), on Africa (Guven \& Leite, 2016; Thovoethin \& Ewalefoh, 2018) and specifically in South Africa (Van dijk \& Mokgala, 2014) interalia, concur that the benefits of universal old age pension schemes are that first they improved the financial position of the elderly beneficiaries to access basic requirements like food so that they could buy basic foodstuffs and get nutrition. Secondly it improved their health because they lived longer because of better nutrition, and they could also afford to pay for health services which become a necessity at old age. Thirdly the pension schemes had another positive impact on access to basic energy services since the elderly recipients could afford to pay for energy sources like paraffin, coal, electricity and others used for cooking, heating, as well as lighting, interalia. Fourthly the pension schemes improved the social welfare of the elderly through better self-esteem as against dependency on, begging and hand outs from economically active members of their household and/ or community. This also improved their mental and emotional health. The fifth positive impact was on the environmental sanitation and hygiene which they are able to manage better due to access to old age pension income. The sixth positive impact was that on household consolidation, since the income is used not only on them but to bring together and maintain the other vulnerable members of their household such as orphans and grandchildren.

These studies also argue that although universal old age pension shielded the elderly from income exclusion and possible failure to access basic needs for life requirements, it did not protect them from inequality because of the differential resource positions of the elderly when they entered into it. Therefore social differentiation and stratification remained unchanged. The second challenge was that in most cases the amounts of money given by the state as old age income were too little to cover the multiple basic requirements of the old age pension recipients. Thirdly this situation was aggravated by the fact that it was often also not adjusted regularly enough to be consistent with rising inflation and cost of living. Fourthly it was based on one person, the old age person, as the beneficiary unit. Yet the reality of developing countries was however, that these elderly recipients lived together with extended families in which they had to share their income and its uses with other household members (Liu \& Sun, 2016; Lal, 2015; Ranya, 2014; Van dijk \& Mokgala, 2014; Guven \& Leite, 2016; Thovoethin \& Ewalefoh, 2018 ).

Therefore Holzmann et al. (2005) writing on behalf of the World Bank propose a model of old age pension that suggests that in order to be fully inclusive and comprehensive old age pension must base on five pillars. There must be a zero pillar which must be noncontributory pension with a focus on the state giving basic income to avoid old age poverty. The first pillar must be contributory but graduated in accordance with income levels of individuals so that they can continue to get a minimum level of their starting income scale at least while they worked help them not to relapse below it in standard of living at pension time. The second pillar must be a compulsory contributory pension that forces a person to do old age savings account. The third pillar must be voluntary and based on the choice and willingness of the individual to contribute either singularly, in collaboration with their employer, or any other agency that handles their contributory pension fund. The fourth pillar must be based on ensuring social security of the elderly in terms of access to basic services such as health care, housing, transport and others through the use of either informal family based and/ or formal agencies driven channels.

While the World Bank model has some credit in that if countries would have policies that have a mixture of the five pillars as far as is possible, they might make an exhaustive old age pension, there remain challenges in terms of inclusivity. For instance in developing countries how does one make people who are not working to engage in the first, second and third pillars which are aspects of contributory old age pension without posing a threat to whatever coping strategies they already use for livelihoods? Moreover as far as the fifth pillar is concerned this is equally controversial even within rich countries themselves in terms of whether health, housing and public transport must be state paid for fully, partially or completely not so at all. For instance, in the United States the ex-President Barak Obama free health policy has become a very heatedly debated political and social policy issue today. In Britain the housing public policy has become an equally heatedly debated issue from one prime ministers to another and their governments with up and down swings for the elderly. With respect to the developing countries implementing the fifth pillar is still largely family driven and/ or based on informal social networks. Regularizing it as part of the old age pension policy would be a positive policy initiative but it will require a lot of financial resources, and it therefore raises issues of affordability by the state. This is more so because even the income oriented social pensions under the zero pillar which are currently 
practiced in many developing countries are encountering financial challenges which pose a threat to their sustainability in many developing countries.

\section{Methodology}

This paper is based on a summary of findings from ongoing research done by students under the theme of spatial aspects of universal old age pension and its impacts in Lesotho done within the context of their degree program requirements in urban and regional planning at the National University of Lesotho (Manosa, 2018; Mokilane, 2019). The study used qualitative and quantitative methods. On qualitative methods, it used desk top methodology for literature review on sustainable livelihood analysis and old age pension. In the case of quantitative methods, primary data was collected from two research sites, one in the Maseru peri-urban area of Ha Matala, and the other in a rural area of Qoqolosing using student researchers. The choice was motivated by the desire to compare and find out whether there would be similarities and/ or differences under urban versus rural settings in terms of the impacts of the old age scheme on the livelihoods of the elderly. In each area a sample of 50 beneficiaries was drawn using a stratified random sampling procedure. A questionnaire was administered to solicit responses from the interviewees. The data was processed and analysed to write this paper.

\section{Results and Discussion}

This section presents the data from the two survey areas in this study and their discussion. The findings of the study reveal that universal old age pension has positive impacts and also challenges for the elderly recipients both in the urban area and rural area alike.

\subsection{Financial Capital and Economic Impacts of the Universal Old Age Pension}

Financial capital entails access to financial resources like income, credit, and economic activities and/ or services that generate and or increase the income and productivity of individuals and/ or households, interalia. Due to the fact that the elderly people have stopped working because of age, they are perceived to be highly vulnerable to lack of/ access to financial capital. This situation makes them to experience financial and economic deprivation, destitution and poverty. Therefore hypothetically, the receipt of old age pension income would enhance their access to financial capital and help them to access goods and services to reduce this vulnerability. This study wanted to find out if and what kind of impacts the universal old age pension had on the financial and economic aspects of the livelihoods of the recipients in the study areas. Therefore they were asked to identify and elaborate on them. The first impact identified was financial injection in the form of direct income. The respondents said it had provided them with access to basic income and thus boosted them financially to be able to afford purchase of basic needs for their living rather than face poverty and destitution. Table 1 presents the data on their response to sources of income.

Table 1. Main Sources of Income of the Respondents by Study Area

\begin{tabular}{|c|c|c|c|c|}
\hline \multirow[b]{2}{*}{$\begin{array}{l}\text { Source } \\
\text { Income }\end{array}$} & \multicolumn{2}{|c|}{ Number of Respondents } & \multicolumn{2}{|c|}{ Percent } \\
\hline & $\begin{array}{c}\text { Ha } \\
\text { Matala } \\
\text { (urban }\end{array}$ & $\begin{array}{c}\text { Qoqolosing } \\
\text { (Rural) }\end{array}$ & $\begin{array}{c}\text { Ha } \\
\text { Matala } \\
\text { (urban) }\end{array}$ & $\begin{array}{c}\text { Qoqolosing } \\
\text { (Rural) }\end{array}$ \\
\hline $\begin{array}{l}\text { Old age } \\
\text { pension }\end{array}$ & 42 & 49 & 84 & 98 \\
\hline Others & 8 & 1 & 16 & 2 \\
\hline Total & 50 & 50 & 100 & 100 \\
\hline
\end{tabular}

Source: Ha Matala and Qoqolosing Old Age Pension Surveys (2018 \& 2019)

Table 1 shows that in Qoqolosing, the rural research site, $98 \%$ of the interviewees said they depended wholly on access to old age pension as the main source of income. They said this was so because family support from their working children had stopped once they received pension income. At Ha Matala, the urban research site, it was $84 \%$ that reported depending on the pension income. This was so because most of them lived with their working children and therefore some of them still received some income hand outs from these children to supplement their pension as part of their contribution to the household budget. These differences indicate that the urban elderly have other sources of income outside old age pension while the rural elderly solely depended on it due to absence of alternative sources. Nonetheless in both the urban and the rural survey sites interviewees were unanimous that the pension income saved them from abject poverty and destitution. Therefore the conclusion of the study was that the old age pension contributed to affording the elderly recipients access to financial capital for livelihood and therefore exclusion from abject poverty.

The challenge reported was that when asked to comment on the sufficiency of the pension income amount of R650 per month, the pension income earners were in agreement that it was too low. Table 2 shows the responses to this issue.

Table 2. Sufficiency of Old Age Pension according to Respondents by Study Area

\begin{tabular}{|c|c|c|c|c|}
\hline \multirow{2}{*}{ Sufficiency } & \multicolumn{2}{|c|}{ Number of Respondents } & \multicolumn{2}{|c|}{ Percent } \\
\cline { 2 - 5 } & $\begin{array}{c}\text { Ha } \\
\text { Matala } \\
\text { (urban }\end{array}$ & $\begin{array}{c}\text { Qoqolosing } \\
\text { (Rural) }\end{array}$ & $\begin{array}{c}\text { Ha } \\
\text { Matala } \\
\text { (urban) }\end{array}$ & $\begin{array}{c}\text { Qoqolosing } \\
\text { (Rural) }\end{array}$ \\
\hline Sufficient & 15 & 27 & 28 & 54 \\
\hline Low & 35 & 23 & 71 & 47 \\
\hline Total & 50 & 50 & 99 & 101 \\
\hline
\end{tabular}

Source: Ha Matala and Qoqolosing Old Age Pension Surveys (2018 \& 2019) 
The statistic was high in the urban area at $71 \%$, while the rural area statistic was $47 \%$ with most of them stating that it made a big difference. The difference was that urban life is highly monetised and urban dwellers used the money to pay for all their basic requirements, while in the rural areas some goods and services are not directly monetised since they are mostly common access goods such as biomass or wood for energy, some water and so on. Hence 54 percent in the rural area site said it was sufficient. Therefore the pension contribution helped the elderly to avoid absolute poverty but they still experienced relative poverty.

The second financial capital contribution was the economic gain. This was reported by the interviewees as increasing their credit to buy producer goods like inputs for crop farming to increase their productivity and efficiency using pension income.

Table 3 shows that some $72 \%$ of the recipients from the rural survey site at Qoqolosing said they had used some of their pension income to buy various inputs needed to boost crop farming activities such as fertilisers, improved seeds, and pesticides, hire labour for weeding and oxen for traction power. On the contrary at the urban site at Ha Matala no expenditure for farming was reported; instead most expenditure went to purchase of luxury/ consumer goods instead of farming, or at least the start up of alternative urban income generating activities. Moreover, in the rural site $24 \%$ reported using pension income to support livestock like building a kraal, buying fodder, hiring a herd boy; paying start up for poultry and piggery. Therefore, the conclusion was that the pension income also contributed to enabling the elderly in the rural community survey area to access economic services to increase their economic productivity and efficiency for a diversified livelihood web to minimise total dependency on the old age pension and poverty.

The challenge faced by the urban site recipients was that none of them reported this use despite the fact that in Lesotho there is no law against their keeping of livestock, poultry and piggery in urban areas. Therefore the conclusion was that their income mainly went for consumer goods for consumption instead of some producer goods as well for moderate investments to enhance their economic assets as happens with some of the rural old pension recipients.

The main challenge was that the low amounts of the pension only allowed for very limited investment in magnitude. This perpetuated a pension dependency syndrome among the elderly in the study areas.

Table 3. Some uses of Old Age Pension by Respondents by Study Area

\begin{tabular}{|c|c|c|c|c|}
\hline \multirow{2}{*}{ Type of Use } & \multicolumn{2}{|c|}{ Respondents } & \multicolumn{2}{c|}{ Percent of the respondents in each of the study areas } \\
\cline { 2 - 5 } & Ha Matala (urban) & Qoqolosing (rural) & Ha Matala (urban research site) & Qoqolosing (rural site) \\
\hline Buy farm inputs & 0 & 36 & 0 & 72 \\
\hline Buy non-farm goods and services & 50 & 13 & 100 & 26 \\
\hline Other & 0 & 1 & 0 & 2 \\
\hline Total & 50 & 50 & 100 & 100 \\
\hline
\end{tabular}

Source: Ha Matala and Qoqolosing Old Age Pension Surveys (2018 \& 2019) 


\subsection{Human Capital and Nutrition, Health and Education Impacts of the Universal Old Age Pension}

Human capital involves, among others, the access to services that improve the welfare of the households or individuals so that that they can become and contribute fit and productive labour in the production of goods and services. It entails good nutrition for health, health services and education and training for skills enhancement. The elderly people are marginalised by lack of income and economic resources and thus experience vulnerability to access to adequate and balanced food for nutrition and health, therefore many are subjected to malnutrition and hunger. Firstly, universal old age pension has positive impacts on improved nutrition and health especially through increased ability to purchase basic food stuffs by the elderly. This study examined this hypothesis and found that on this impact $80 \%$ of the recipient respondents from the rural site at Qoqolosing said they now had access to food, they could buy basic food items, eat one to three times a day, and could occasionally also buy some variety for balanced diet; all of which improved their health. At the urban site at Ha Matala, $17 \%$ of the interviewed pension recipients stated that they used all the pension income on food; $37 \%$ said they used R500 of it, and $47 \%$ used between R200 - R500 of the overall R650 monthly income on food. Types of the most preferred types of food purchased from old age pension income were investigated. The results are presented in Table 4 below.

Table 4. Some food items purchased with Old Age Pension as percentage of Respondents by Study Area

\begin{tabular}{|c|c|c|}
\hline \multirow{2}{*}{ Type of food } & \multicolumn{2}{|c|}{ Percent of respondents } \\
\cline { 2 - 3 } & Ha Matala (urban) & Qoqolosing (rural) \\
\hline Maize meal & 27 & 11 \\
\hline Vegetables & 25 & 6 \\
\hline Meat & 11 & 10 \\
\hline Beans & 8 & 0 \\
\hline Eggs & 5 & 5 \\
\hline Sugar & 0 & 12 \\
\hline Tea & 0 & 11 \\
\hline Bread flour & 0 & 11 \\
\hline Cooking oil & 0 & 9 \\
\hline Other & 24 & 25 \\
\hline
\end{tabular}

Source: Ha Matala and Qoqolosing Old Age Pension Surveys (2018 \& 2019)
Table 4 shows that the types of food variety reported by respondents from the urban site as purchased were mostly maize meal at $27 \%$, vegetables at $25 \%$, meat at $11 \%$, beans at $8 \%$, and eggs at $6 \%$ and other smaller food varieties. The goods purchased and consumed in priority by the rural area community were reported to be sugar at $12 \%$, tea at $11 \%$, maize meal at $11 \%$, bread flour at $11 \%$, meat at $10 \%$, cooking oil at $9 \%$, vegetables at $6 \%$, and eggs at $5 \%$. These major food items consumed indicate that the universal old age pension enables the elderly to consume a balanced diet good for their nutrition and health. In Africa including Lesotho, the elderly are a repository and source of wisdom and custodians of knowledge; they are also defacto and dejure heads of households who bring up their orphaned grandchildren whose parents have been victims of rampant HIV/AIDS pandemic. Therefore their good health enables them to perform these functions better. Therefore, the study concluded that old age pension contributed to human capital via nutrition in the two survey areas. The challenge was that at the rural community some food items prioritized might actually endanger the health status of the elderly especially the sugar, tea and oil, which are major contributors to high blood pressure and sugar diabetes to which the elderly are prone.

Another challenge related to the inclusivity of the beneficiaries in the old age pension. Officially old age in Lesotho as well as in many other countries starts at 60 years. This means that by putting the legibility age at 70 years and above, there is a 10 years gap of people between 60 to 69 years old who are legally old, but officially excluded from access to pension. This group of the elderly remains exposed to vulnerability of aging trends and resultant shocks by the structures and processes that jointly execute the old age pension scheme in Lesotho.

The old age pension is also gender inclusive. Table 5 presents the gender profile of the sampled respondents in each of the two survey areas.

Table 5 shows that in the study, the rural area pension recipients interviewed were $62 \%$ female and men were $38 \%$. In the urban area respondents there were $56 \%$ female recipients and $44 \%$ male recipients. By including women as beneficiaries too the universal old age pension ensured that the elderly women had access to financial capital that enabled them to have capacity to enhance their skills and income through engaging in endeavours like kitting, sewing, poultry and piggery. Moreover, the pension enabled the recipient women to have access to human, natural and physical capital services as well independently of men, even if they are married. 
Table 5. Gender of Old Age Pension Sampled Recipients by Study Area

\begin{tabular}{|c|c|c|c|c|}
\hline \multirow{2}{*}{ Gender } & \multicolumn{2}{|c|}{ Number of Respondents } & \multicolumn{2}{|c|}{ Percent } \\
\cline { 2 - 5 } & Ha Matala (urban & Qoqolosing (Rural) & Ha Matala (urban) & Qoqolosing (Rural) \\
\hline Women & 28 & 31 & 56 & 62 \\
\hline Men & 22 & 19 & 44 & 38 \\
\hline Total & 50 & 50 & 100 & 100 \\
\hline
\end{tabular}

Source: Ha Matala and Qoqolosing Old Age Pension Surveys (2018 \& 2019)

The second human capital contribution was to direct health impacts. In the study, $52 \%$ of the pension income recipients at the rural community said they had better health afterwards because they could go to the clinic when sick, pay for their grandchildren when sick, had no more income stress and related illnesses. In the urban community it was $27 \%$ who said they could afford better health after getting pension income; while $73 \%$ said they continued to have ill health because the pension money was too little to have some left to spend on health services after purchase of basic requirements with it. These differences indicated that the rural community had higher priority compared to the urban community in relation to the use of pension income for health. The general conclusion of the study was that old age pension contributed to the improvement of and access to human capital assets and services in both the urban and rural survey areas.

The third human capital contribution was in relation to education. The elderly are mostly heads of grandparent headed households in Lesotho because of desertion of children, unemployment or early death of their parents due to HIV/AIDS pandemic. Therefore their education is a task left in the hands of their grandparents who look up to them for support. In the study none of the two study areas mentioned use of the pension money for education and/ or training of any kind or associated complimentary educational services for their grandchildren. This was so because in Lesotho since the year 2000 there is free primary education under universal education for all. Moreover, a free bursary scheme is run for orphaned and vulnerable children for post primary education. Therefore the conclusion was that old age pension did not contribute to the human capital via education in the study areas.

\subsection{Social Capital and Related Impacts of the Universal Old Age Pension}

Social capital deals with, interalia, access to the various social assets including social networks and institutional connections that individuals or households get attached to in order to enhance their social environment to facilitate their access to assets and livelihood. Access to most of these social capital assets is, interalia, through paid up membership. This promotes the exclusion of elderly people who do not have the money with which to pay for membership. In the study the use of the old age pension income for social capital was reported. In the rural community area, $83 \%$ said they had used some part of their pension income to pay fees for their membership of a community scheme. In the urban area there was no one who reported using part of their pension for social networks like community schemes and others. The study concluded that the latter were spatial differences on the use the pension income for social networks between the urban and rural interviewees.

\subsection{Natural Capital and Environmental Resources Impacts of the Universal Old Age Pension}

Natural capital covers, among other things, issues of direct access to services to enhance environmental resources needed for livelihood by individuals or households. Access to land, other natural resources and the ability to maintain them well influences the extent to which elderly people can make a living from natural capital assets. Where these assets are paid for, access to them may not be afforded by the elderly due to lack of income. Where they are regulated by the market and there is ground or other tax levied on them, even those elderly people who had access to them might lose them due to failure to keep up with the required annual rents or taxes for their upkeep. In Lesotho rural land is not yet paid for in either way; while urban land is paid for through purchase of residential plots and/ or annual ground rent for them.

At Qoqolosing, the rural area of this study, no one reported purchase of land through the use of part of the old age pension income. However, $71 \%$ said they had used part of it to buy inputs and services to improve its productivity of crops. This promoted enhancement of the quality of their land as natural capital. In Ha Matala, the urban area of this survey, $1 \%$ of the interviewees reported using part of their pension to pay bills for purchase of water from the Water and Sewerage Company (WASCO), 2\% said they purchased gas with part of their old age pension. Therefore the study concluded that the old age pension did contribute to access to the natural capital in the two survey communities by some of the elderly recipients. The challenge is that these contributions can also fall under the economic aspects of financial capital for land services for farming reported in the rural area; while the water and gas purchase reported in the urban area can also fall under access to physical capital. 


\subsection{Physical Capital and Infrastructure Impacts of the Universal Old Age Pension}

Physical capital deals with access to fixed as well as movable stocks and services which are infrastructural in nature, interalia. It covers housing and access to shelter services, communications, energy and transport and so on. In particular, the elderly experience vulnerability with regard to access to adequate shelter services and housing due to lack of income. Where they have housing of their own it is in a depreciated unacceptable state due to lack of maintenance. Sometimes the elderly are completely shelter less or homeless and live under the protection of relatives or good Samaritans within the community. This promotes their deprivation and poverty. In the study the use of part of the old age pension income for physical capital was reported by $43 \%$ in the rural survey area; of whom $16 \%$ said they did major repairs to their houses, $17 \%$ said they bought household equipments, $7 \%$ painted their houses and $3 \%$ bought household furniture with part of the old age pension income. In the urban survey area, there was no mention of using part of the old age pension for any housing purchase or improvement of housing conditions. Instead mention by $1 \%$ was of payment of water bills; and purchase of gas for energy services by $2 \%$. Therefore the study concluded that in the rural area the old age pension contributed to the construction of physical capital through better housing and shelter while it did so in the urban study area on access to energy and water services for poverty reduction.

\section{Conclusions and Recommendations}

This paper concludes that Lesotho's experience with universal old age pension scheme is to be heralded for its contribution to intergenerational poverty reduction on the elderly urban and rural population within the study areas. Although these impacts show some differences in spatial terms between rural and urban study sites as pointed out in the text, they however, were positive across these two spaces. The elderly were found to be no more left behind in reducing poverty in line with SDG 1 of the United Nations Agenda 2030. In particular, the major findings were that old age pension recipients interviewed in the samples in the study areas were happy with it as a strategy to relief them from and help them in poverty reduction. It found that they said they were able to have access to basic goods and some services for livelihoods such as food, some inputs, health services, payment of membership to community societies, payments for improvements to their land and of water bills, and renovations to some of their housing properties, interalia. Therefore in terms of the sustainable livelihoods framework the universal old age pension contributed positively to economic capital, human capital, social capital and physical capital in the study areas. Therefore it concluded that the old age pension had positive impacts on inclusive development in urban and rural area. However, the study also found that it failed to include people falling within the early old age group of between 60 to 69 years. This group, which is already pensioned from work due to old age, was left behind exposed to lack of access to sustainable livelihoods. Moreover, while the universal old age pension had positive impacts on promoting access to financial and human capital in the urban and rural areas of the study areas; it simultaneously had differential impacts on natural, physical and social capital in favour of the rural area. Furthermore, the study concluded that the universal old age pension seemed to be aimed at poverty reduction and access to livelihoods from the financial viewpoint only, and yet poverty is multidimensional. Therefore, it recommended that the amount of the pension income be adjusted upwards to the basic poverty datum line for the country so as to enable the elderly recipients to cope with multidimensional poverty both in the rural and urban areas. On the whole, spatially, the impacts of universal old age pension were felt more in the rural than the urban area of the study.

\section{REFERENCES}

[1] African Economic Outlook (2012). Lesotho 2012. Retrieved from www.africaneconomicoutlook.org.

[2] Department for International Development (DFID) (1999). Sustainable Livelihoods Guidance Sheets. London: DFID.

[3] Guven, M. and Leite, P. (2016). Benefits and Costs of Social Pensions in Sub- Saharan Africa. World Bank Discussion Paper No. 1607. Washington DC: World Bank. Retrieved from www.documents.worldbank.org/curated/en/3252814 $69593828257 / \mathrm{pdf} /$

[4] Index mundi (undated). Lesotho - Income Distribution. Retrieved from www.indexmundi.com/facts/lesotho/incom e-distribution.

[5] Government of Lesotho (2005). Old Age Pensions Act. Maseru: Government Printer.

[6] Government of Lesotho (2014). Lesotho Policy for Older Persons. Maseru: Ministry of Social Development.

[7] Holzmann, R. et al. (2005). Old Age Income Support in the $21^{\text {St }}$ Century. Washington, D.C. World Bank.

[8] Kingdom of Lesotho (2013). Millennium Development Goals Status Report. Maseru: Ministry of Development Planning.

[9] Kingdom of Lesotho (2014). National Social Protection Strategy 2014/15 - 2018/19. Maseru: Ministry of Social Development.

[10] La, S. (2015). National Old Age Pension Scheme in India: A study in Karimnagar District of Telangana State. Academicia: An International Multidisciplinary Research Journal, 5(6), 276 - 287.

[11] Liu, T, \& Liu, L. (2016). Pension Reform in China. Journal 
of Aging and Social Policy, 28(1). Retrieved from https://doi.org./10.1080/08959420.2016.1111725.

[12] Manosa, M. (2018). Old Age Pension and Livelihoods at Ha Matala in Maseru. A B.A in Urban and regional Planning Research Project. Roma: National University of Lesotho.

[13] Ministry of Education (2015). Review of Education for All (EFA) Programme. Maseru: MOET.

[14] Mokilane, N. (2019). Old Age Pension and Livelihoods of the elderly at Qoqolosing in Leribe. A B.A in Urban and Regional Planning Research Project. Roma: National University of Lesotho.

[15] Ramya, T. (2014). The Old Age Pension and its impact on the livelihood chances of elderly tribal people of Arunachal Pradesh, India. In S. Pandey \& J. Singh (Eds.), Handbook of Management, Technology and Social Sciences. Adobe Acrobat Reader. Retrieved from https://researchgate.net/

[16] Shakya, M. (undated). Lesotho: The state's role in building a critical mass for competitiveness in apparel exports. Oxford: University of Oxford.

[17] Shin, E. \& Kyung Do, Y. (2015). Basic Old Age Pension and financial wellbeing of older adults in South Korea. Age \& Society, 35, 1055-1074. Retrieved from https://www.camb ridge.org/core/service/aop-cambridge-core/.

[18] Thovoethin, P. \& Ewalefoh, J. (2018). Universal Old Age Pension: Can Africa Overcome its Challenges? Africa's Public Service Delivery and Performance Review, 6(1), 232. https://doi.org/10.4102/apsdpr.v6i1.232

[19] Valdes-Rodriguez, O. \& Perez-Vazquez, A. (2011). Sustainable Livelihoods: Analysis of Methodology. Tropical and Subtropical Agroecosystems, 14, 91-99.

[20] Willmore, L. (2006). Universal Pensions for Developing Countries. Retrieved from https://www.researcgate.net/pub lications/222705094 on 17/10/2019. 